\title{
Rad-Oplus-Supplemented Lattices
}

Çiğdem Biçer ${ }^{1}$ and Celil Nebiyev ${ }^{2}$

${ }^{1}$ Ondokuz Mayis University

${ }^{2}$ Ondokuz Mayis Universitesi

May 5, 2020

\begin{abstract}
In this work, we define Rad-oplus-supplemented and strongly Rad-oplus-supplemented lattices and give some properties of these lattices. We generalize some properties of Rad-oplus-supplemented modules to lattices.
\end{abstract}

\section{Hosted file}

Rad-+-Supplemented Lattices.pdf available at https://authorea.com/users/296723/articles/ 425744-rad-oplus-supplemented-lattices 